\title{
TANTANGAN KONSEP PERDAGANGAN SUKUK DI PASAR SEKUNDER
}

\author{
Hanandewa $^{1}$; Mohamad Heykal ${ }^{2}$ \\ ${ }^{1}$ Praktisi dan kandidat doktor ilmu keuangan dari Graduate School of Business, Universiti Kebangsaan Malaysia \\ ${ }^{2}$ Accounting and Finance Department, Faculty of Economics and Communication, BINUS University \\ Jln. KH Syahdan No. 9, Palmerah, Jakarta Barat 11480 \\ mheykal@binus.edu
}

\begin{abstract}
Sukuk trading mechanisms in most exchange-based secondary market around the globe are somehow depart from the shariah law. The trading mechanisms basis are dominated by bai' al dayn concept which is against the shariah law. Much of the motives to adopt this concept are to cater conventional investors demand for familiarity in trading mechanism with conventional bond. Though, it may also hamper Muslim-devoted investors to trade their sukuk because of this noncompliance to the shariah law. On the other hand, a trading mechanism that fully complies with the shariah law would probably cause anxiety to conventional investors that comprise much of the investors profile in this contemporary financial environment. This paper that based on the literature study try to proposes a new trading mechanism to minimize the trade-off between conventional and Muslim-devoted investors needs in their sukuk trading in exchange-based secondary market.
\end{abstract}

Keywords: sukuk, trading, mechanism, investors, secondary, market

\begin{abstract}
ABSTRAK
Mekanisme perdagangan sukuk pada sebagian pasar sekunder di dunia telah menyimpang dari hukum syariat. Dasar mekanisme perdagangan ini lebih didominasi oleh konsep bai' al dayn di mana konsep ini bertentangan dengan hukum syariat. Dari segi akuntansi, akad ini juga tidak diakui. Motivasi utama dalam mengadopsi konsep ini tampaknya lebih banyak dipergunakan untuk melayani permintaan investor konvensional terhadap konsep mekanisme perdagangan dengan obligasi konvensional yang biasa dikenal. Meskipun hal ini dapat pula menghalangi investor Muslim yang taat dalam memperdagangkan sukuk mereka karena ketidakpatuhan terhadap hukum syariat. Di sisi lain, sebuah mekanisme perdagangan yang patuh sepenuhnya kepada hukum syariat mungkin dapat menyebabkan kekhawatiran bagi investor konvensional yang merupakan sebagian besar profil investor dalam lingkungan keuangan modern saat ini. Artikel yang menggunakan metode penelitian berbasis studi literatur ini mencoba menawarkan sebuah mekanisme perdagangan baru untuk mengurangi benturan antara kebutuhan investor konvensional dengan investor Muslim yang taat dalam memperdagangkan sukuk mereka di bursa pasar sekunder.
\end{abstract}

Kata kunci: sukuk, perdagangan, mekanisme, investor, pasar, sekunder 


\section{PENDAHULUAN}

Salah satu instrumen investasi dalam pasar modal syariat adalah sukuk. Berkaitan dengan sukuk maka perlu dilihat dahulu pengertian tentang sukuk. Terdapat beberapa pengertian akan sukuk. Akan tetapi, pengertian tersebut harus melihat juga asal kata dari sukuk itu sendiri. Asal kata dari sukuk adalah sakk, atau kadang kala juga sakaik. Kata-kata tersebut biasanya digunakan untuk kegiatan perdagangan internasional yang terjadi di berbagai wilayah yang dikuasai oleh pemerintahan Islam pada masa abad pertengahan. Berbagai fakta yang ada menunjukkan bahwa sukuk yang ada banyak dipergunakan oleh berbagai masyarakat muslim dalam abad pertengahan dalam bentuk-bentuk surat berharga yang mewakili kewajiban pembiayaan yang berasal dari perdagangan dan juga berbagai kegiatan komersial lainnya. Meskipun begitu, pengertian sukuk yang paling tepat adalah sertifikat investasi.

Pengertian tersebut tidak terlalu berbeda jauh dengan pengertian AAOIFI tentang sukuk, yang dikeluarkan pada Mei 2003. Dalam pengertian tersebut dikatakan bahwa suk merupakan " sertifikat dengan nilai yang sama yang mewakili bagian kepemilikan yang sepenuhnya terhadap aset yang nyata (tangible). Denga kata lain, penerbitan instrumen sukuk harus dilandasi dengan aset yang nyata, dan investor dari sukuk akan mendapatkan keuntungan sebagai bagian yang tidak dapat dipisahkan dari aset yang melandasi sukuk tersebut. Sebagai konsekuensi dan akibat dari pengertian tersebut, keuntungan yang didapatkan oleh investor sukuk harus dibagi kepada sesama investor sukuk tersebut.

Dalam beberapa kurun waktu terakhir ini, sukuk telah meraih popularitasnya sebagai salah satu alternatif instrumen pembiayaan di samping obligasi konvensional. Di beberapa negara, diketahui bahwa sukuk telah menjadi instrumen pembiayaan anggaran negara yang penting. Pada saat ini, beberapa negara telah menjadi regular issuer dari instrumen sukuk, misalnya Malaysia, Bahrain, Brunei Darussalam, Uni Emirat Arab, Qatar, Pakistan, dan State of Saxony Anhalt - Jerman. Penerbitan sovereign sukuk biasanya ditujukan untuk keperluan pembiayaan negara secara umum (general funding) atau untuk pembiayaan proyek-proyek tertentu, misalnya pembangunan bendungan, unit pembangkit listrik, pelabuhan, bandar udara, rumah sakit, dan jalan tol. Selain itu, sukuk juga dapat digunakan untuk keperluan pembiayaan cash-mismacth, yaitu dengan menggunakan sukuk dengan jangka waktu pendek (Islamic Tresury Bills) dan juga dapat digunakan sebagai instrumen pasar uang.

Selama periode 2004-2007, penerbitan sukuk secara global telah meningkat dengan signifikan dari USD 7,2 milyar pada 2004 menjadi USD 39 milyar pada akhir 2007 (Jobst et al., 2008). Berdasarkan tren 2004-2007 tersebut, Jobst et al. (2008) memperkirakan jumlah sukuk secara global yang beredar akan mencapai lebih dari USD 200 milyar pada akhir 2010. Berdasarkan proyeksi yang dilakukan oleh S\&P, dalam lima tahun ke depan, pasar sukuk dunia dapat menembus level USD 100 miliar. Hal ini tergantung pada kondisi stabilitas pasar kredit. Sementara itu, pihak Moody memperkirakan, pasar sukuk akan meningkat sebesar 35 persen per tahun. Pada 2010, pasar sukuk global diharapkan dapat menembus hingga USD 200 miliar, terutama ditopang oleh negara-negara di kawasan Teluk yang tergabung dalam GCC, Inggris, Jepang, dan Thailand (MIFC, 2009). Potensi volume yang sangat besar ini tentunya perlu diimbangi dengan keberadaan pasar sekunder sukuk yang kokoh untuk dalam rangka memfasilitasi kebutuhan investor. Grafik di bawah ini menunjukkan perkembangan sukuk dunia. 


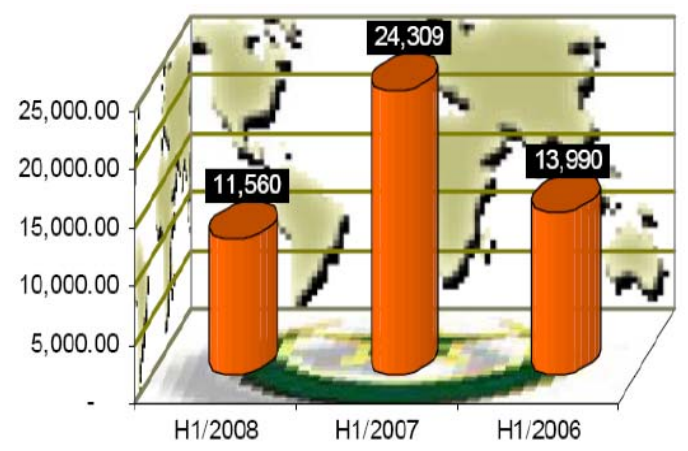

Gambar 1 Total Penerbitan Sukuk (USD Juta) Perbandingan Semester I 2006, 2007, 2008

(A Possible Impact Of Sub-Prime Crisis)

(Sumber: Beard, Charles dalam Ali, 2008)

Seperti diketahui bahwa pasar sekunder dalam pasar modal akan sangat membantu investor yang memerlukan likuiditas untuk dapat menjual surat berharga yang dimilikinya. Begitu pula dengan investor sukuk dapat melakukan pemaparan sukuk tersebut dalam pasar sekunder yang pada akhirnya akan meningkatkan pengamatan para calon pembeli sukuk. Demikian pula sebaliknya, pasar sekunder juga membantu investor yang memiliki kelebihan likuiditas untuk dapat membeli sukuk dengan cara mengekspos minatnya tersebut terhadap pengamatan para calon penjual sukuk. Dalam hal ini, pasar sekunder membantu menyediakan likuiditas bagi sukuk dan selanjutnya akan menarik lebih banyak investor karena kemudahan bagi investor untuk masuk ke pasar maupun keluar dari pasar. Oleh karena itu, tingginya aktivitas perdagangan sukuk di pasar sekunder pada akhirnya akan meningkatkan pula volume penerbitan sukuk.

Namun demikian, praktik perdagangan sukuk saat ini di pasar sekunder di hampir seluruh dunia memiliki satu masalah dalam mekanisme perdagangannya. Mekanisme perdagangan sukuk ini banyak menyimpang dari hukum syariat. Adopsi terhadap konsep bai’ al dayn, dan bukannya konsep hawalah, dalam mekanisme perdagangan sukuk telah menyebabkan penyimpangan ini; dimana tampaknya hal ini dimotivasi oleh keinginan untuk melayani permintaan investor konvensional terhadap familiaritas mekanisme perdagangan dengan obligasi konvensional. Padahal sukuk merupakan investasi yang tidak bisa disamakan dengan obligasi. Sukuk merupakan surat berharga yang memiliki sifat sebagai bukti kepemilikan atas manfaat ataupun aset dan jasa tertentu dengan landasan aset tertentu sebagai basis dari transaksi. Hal ini berbeda dengan obligasi yang merupakan surat pernyataan utang tanpa adanya aset tertentu yang mendasarinya.Selain dari sisi landasan aset yang mendasarinya, perbedaan antara konsep obligasi dengan sukuk adalah dari sisi perdagangan instrumen tersebut. Instrumen sukuk merupakan instrumen yang dapat diperdagangkan, termasuk untuk diperjualbelikan. Fatwa Dewan Syariah Nasional nomor 32 tentang obligasi syariat dan juga standar AAOIFI tentang sukuk telah menyatakan bahwa kepemilikan instrumen obligasi syariat yang kemudian dtetapkan sebagai sukuk mengikuti berbagai akad yang dipergunakan. Hal inilah yang membuat konsep bay 'al dayn menjadi hal yang diperdebatkan karena merupakan konsep jual beli piutang.

Meskipun hal ini dapat pula menghalangi investor Muslim yang taat dalam memperdagangkan sukuk mereka karena ketidakpatuhan terhadap hukum syariat. Di sisi lain, sebuah mekanisme perdagangan yang patuh sepenuhnya kepada hukum syariat mungkin dapat menyebabkan kekuatiran bagi investor konvensional yang merupakan sebagian besar profil investor dalam lingkungan keuangan modern saat ini. Sebuah mekanisme perdagangan baru dibutuhkan agar kedua profil investor ini, investor konvensional dan investor Muslim yang taat, dapat memperdagangkan sukuk mereka di bursa pasar sekunder. Melalui mekanisme perdagangan yang baru ini yang mampu merangkul kedua profil investor tersebut, diharapkan dapat membantu mencapai tujuan dari sebuah bursa pasar sekunder yaitu memberikan likuiditas yang lebih baik dan meningkatkan volume sukuk. 


\section{METODE PENELITIAN}

Penelitian ini merupakan penelitian yang berbasis pada studi literatur. Seperti diketahui bahwa menurut pandangan para ahli keuangan syariat, suatu instrumen investasi syariat dapat diperdagangkan dalam pasar sekunder, selama instrumen tersebut memenuhi tiga aturan syariat (Ayub, 2007). Pertama, instrumen-instrumen yang merepresentasikan kepemilikan atas aset fisik riil maupun hak pemanfaatannya (usufruct) dapat diperdagangkan pada harga pasar. Kedua, instrumen-instrumen yang merepresentasikan kepemilikan atas utang dan uang dapat diperdagangkan namun terikat kepada konsep hawalah dan bai' al sarf. Dan ketiga, instrumen-instrumen yang merepresentasikan kepemilikan atas suatu kumpulan instrumen dengan kelas yang berbeda terikat kepada aturan atas kelas instrumen yang dominan.

Berdasarkan pada ketiga aturan ini, maka sukuk sebenarnya dapat diperdagangkan dalam pasar sekunder. Namun demikian, perhatian secara khusus perlu diberikan dalam menerjemahkan arti dari konsep hawalah tersebut. Terdapat perbedaan yang nyata antara konsep hawalah (pengalihan utang) dan bai' al dayn (penjualan utang). Dalam kasus jual beli surat utang di pasar sekunder mengikuti konsep hawalah, yang dibenarkan dalam syariat, pihak pembeli surat utang memiliki hak recourse kepada pihak penjual surat utang bilamana pihak penerbit surat utang tidak membayar utangnya oleh sebab apapun juga. Di sisi lain, dalam kasus yang sama mengikuti konsep bai' al dayn, yang tidak dibenarkan dalam syariat, pihak pembeli surat utang tidak memililki hak recourse kepada pihak penjual surat utang.

Meskipun sukuk dapat diperdagangkan, sampai dengan saat ini perdagangan sukuk di bursa pasar sekunder secara global masih sangat minim, terutama di negara-negara GCC (Gulf Cooperation Council). Hal ini kemungkinan besar disebabkan karena permintaan masih cukup melebihi dibandingkan pasokannya dan sebagian besar investor di negera-negara tersebut (GCC) pada umumnya menahan hingga jatuh tempo (Abbas, 2005). Selain itu banyak investor yang menjadikan instrumen sukuk sebagai investasi jangka panjang mereka. Pada tingkat global, sukuk yang tercatat (listed) di bursa hanya mencakup 14,3\% dari nilai sukuk seluruhnya yang beredar selama kurun waktu 2001-2007 (Papazian, 2007).

Berdasarkan dari sumber yang sama, sukuk yang tercatat di bursa Indonesia memimpin dalam hal jumlah pencatatan (15,3\% dari jumlah sukuk yang tercatat di bursa secara global), diikuti oleh bursa UEA (14,2\%). Kenyataan bahwa bursa Indonesia memimpin dalam hal jumlah pencatatan sukuk merupakan hal yang cukup menarik, terlepas dari kehadiran Indonesia di pasar sukuk yang masih relatif baru dan hanya mengambil fraksi kecil dalam nilai sukuk seluruhnya yang beredar secara global. Sedangkan UEA sendiri selama ini telah secara aktif mengkonsolidasikan perdagangan pasar sekundernya pada Dubai International Financial Exchange (DIFX), hingga menjadikannya memiliki nilai pasar sukuk tercatat yang tertinggi di dunia (Jobst et al, 2008). Di sisi lain, Malaysia yang merupakan pemimpin dalam penerbitan sukuk global dengan kontribusi $65,7 \%$ atas pangsa pasar pada 2005, tampaknya masih perlu mengembangkan lagi bursa pasar sekunder untuk sukuknya. Meskipun saat ini pasar sekunder sukuk Malaysia dapat dianggap sebagai yang paling likuid, sebagian besar diperdagangkan pada pasar OTC (over-the-counter) dan bukan di bursa efek. Salah satu karakteristik perdagangan di pasar OTC biasanya ditandai dengan marjin yang cukup besar bagi pialangnya (broker). Sehingga hal ini memberikan keengganan bagi para pialang untuk mengembangkan pasar berbasis bursa yang transparan dan likuid karena dapat mengurangi marjin mereka melalui adanya kompetisi (Marek, 2007). Suatu hal yang anomali, mengingat proses filterisasi konsep pasar modal syariat di Malaysia tidak seperti di Indonesia (Karim, 2012).

Selain itu, sekali seorang investor terlibat dalam perdagangan di pasar OTC, maka bila dia hendak melakukan perdagangan kembali pada masa mendatang, kemungkinan besar dia akan memilih 
untuk kembali ke pialang yang sama karena alasan kemudahan dokumentasi. Ini merupakan keuntungan lagi bagi pialang bersangkutan. Semua hal tersebut mungkin dapat menjelaskan pertumbuhan yang lambat pada pasar sekunder sukuk berbasis bursa. Akan tetapi, secara logika, berkurangnya marjin yang diperoleh pialang karena munculnya pasar sekunder berbasis bursa yang transparan dapat dikompensasi oleh pertumbuhan volume bisnis dan peluang perdagangan.

Perkembangan terkini dalam perdagangan sukuk di pasar sekunder telah menuai beberapa kritik karena beragamnya pemahaman terhadap aturan syariat. Sebagai contoh di Malaysia, yang mendominasi nilai penerbitan sukuk secara global, sebagian besar sukuk yang diterbitkan adalah berbasis kepada konsep bai' al 'inah dan tabarru', sementara perdagangannya di pasar sekunder berbasis kepada konsep bai' al dayn (Ayub, 2007). Ketiga konsep ini pada prinsipnya bertentangan dengan hukum syariat. Hal ini sesuai dengan fakta yang ada dalam pasar modal syariat di Malaysia bahwa dalam proses seleksi yang dilakukan dalam bursa efek Malaysia tidak terlalu ketat seperti 5\% dari keuntungan perusahaan masih boleh berbasiskan pinjaman berbunga ( Karim, 2012 ). Konsep bai' al 'inah sendiri pada dasarnya hampir sama dengan transaksi repo dalam terminologi keuangan konvensional, yaitu penjualan berganda dimana terjadi penjualan dan penjualan kembali suatu instrumen antara pihak pembeli dan penerbit sendiri yang mana hasil akhirnya adalah sama dengan suatu pinjaman dengan bunga. Sedangkan tabarru' adalah menjanjikan suatu imbal hasil (return) tertentu kepada investor sukuk, terlepas dari arus kas proyek yang dijadikan underlying atas sukuk tersebut. Praktik tabarru' meliputi pembagian secara tetap (reguler) kepada pemegang sukuk dan menjamin pengembalian pokoknya.

Beberapa pakar keuangan syariat dari Malaysia berpendapat bahwa jual beli surat utang di pasar sekunder dibenarkan berdasarkan aturan dari paham Syafii. Akan tetapi, argumen ini mungkin melupakan kenyataan bahwa para ahli hukum Syafii sendiri hanya memperbolehkan jual beli surat utang dalam kasus dimana surat utang tersebut diperjualbelikan pada nilai nominalnya (Ayub, 2007). Kritikan lainnya ditujukan pada praktik menjangkarkan imbal hasil sukuk ke LIBOR (London Interbank Offered Rate) atau tingkat suku bunga lokal ekuivalen lainnya. Meskipun beberapa pihak berargumen bahwa hal tersebut hanya digunakan dalam penghitungan harga, bahkan metode ini juga sering kali dipakai oleh Islamic Development Bank (IDB), namun demikian pembayaran imbal hasil sukuk yang dikaitkan dengan suatu tingkat suku bunga konvensional dapat dianggap sebagai rente atau riba (Usmani, 2002). Dalam penelitian yang tidak berkaitan dengan sukuk, seperti tentang kajian pembiayaan dengan akad murabahah (Heykal, 2006) yang merujuk pada penelitian tentang upaya memurnikan pembiaayaan Murabahah (Karnaen, 2002), hal ini juga sudah ditegaskan.

Semua perkembangan terkini sukuk ini sangat mungkin dilandasi oleh masalah yang dihadapi lembaga keuangan yang menerbitkan instrumen tersebut dalam rangka menampilkan sukuk sebagai suatu hal yang identik dengan obligasi konvensional, karena akan memudahkan dalam penilaian risiko oleh investor. Investor akan merasa lebih percaya diri untuk berinvestasi pada surat berharga yang memiliki struktur yang tidak asing bagi mereka daripada surat berharga dengan struktur yang asing dan juga dengan istilah yang mungkin terdengar baru. Sehingga, inovasi terhadap sukuk lebih banyak pada sisi hukumnya agar patuh terhadap hukum syariat namun belum ada inovasi secara finansial (Wilson, 2008). Hal ini dapat diamati pada pembentukan harga pasar sukuk di pasar sekunder. Jika tidak ada inovasi baru secara finansial pada sukuk, harga pasar sukuk akan sama sensitifnya seperti obligasi konvensional terhadap variabel tingkat suku bunga pasar. Berdasarkan model valuasi obligasi konvensional, dinyatakan bahwa harga obligasi akan lebih tinggi dari nilai nominalnya ketika tingkat suku bunga pasar yang sebanding dengannya lebih rendah daripada tingkat kuponnya. Dan sebaliknya harga obligasi akan lebih rendah dari nilai nominalnya ketika tingkat suku bunga pasar yang sebanding dengannya lebih tinggi daripada tingkat kuponnya; atau diekspresikan melalui persamaan sebagai berikut (Brigham et al., 1999): 


$$
V=\sum_{t=1}^{n} \frac{C}{(1+Y)^{t}}+\frac{P}{(1+Y)^{n}}
$$

dimana: $\quad V$ adalah nilai pasar obligasi,

$C$ adalah pembayaran kupon secara periodik,

$P$ adalah pembayaran pokok pada saat jatuh tempo,

$Y$ adalah tingkat suku bunga pasar yang sebanding, dan

$n$ adalah jumlah periode pembayaran kupon

Valuasi tersebut akan menentukan keputusan investor untuk melakukan pembelian sukuk atau tidak. Jika proses valuasi sukuk mengikuti model valuasi obligasi konvensional, proses pembentukan harga sukuk di pasar sekunder tampaknya tidak sepenuhnya mematuhi hukum syariat. Hal ini dikarenakan model valuasi obligasi konvensional memperhitungkan efek bunga majemuk atas uang yang tidak dapat dibenarkan dalam konsep keuangan syariat. Dalam syariat, uang seharusnya digunakan sebagai satuan ukuran dan bukan sebagai suatu aset yang dapat menghasilkan penghasilan sendiri dan juga bukan aset yang diperdagangkan. Sehingga, ketika investor menghitung harga sukuk menggunakan model valuasi obligasi konvensional maka hal ini telah melanggar larangan terhadap riba.

Menanggapi hal ini, Papazian (2007) mengajukan sebuah model valuasi yang serupa dengan persamaan (1), namun dia berargumen bahwa imbal hasil yang digunakan seharusnya mencerminkan imbal hasil atas aktivitas produktif atau imbal hasil riil (real return), dan bukannya tingkat suku bunga pasar. Hal ini dapat diekpresikan sebagai berikut:

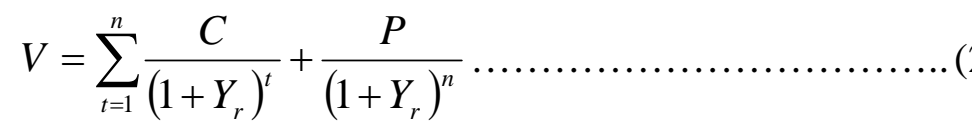

dimana: $\quad V$ adalah nilai pasar obligasi,

$C$ adalah pembayaran kupon secara periodik,

$P$ adalah pembayaran pokok pada saat jatuh tempo,

$Y_{r}$ adalah imbal hasil riil, dan

$n$ adalah jumlah periode pembayaran kupon.

Menurut Papazian (2007), imbal hasil riil berbeda dengan tingkat suku bunga yang digunakan dalam model valuasi obligasi konvensional, dimana tingkat suku bunga hanya mencerminkan kompensasi terhadap modal dan waktu. Imbal hasil riil adalah suatu imbal hasil yang dihasilkan oleh suatu investasi yang memperhitungkan tidak hanya modal dan waktu. Secara spesifik, suatu imbal hasil riil mencerminkan kompensasi terhadap modal dan sumber daya selain waktu. Dalam hal ini, suatu pembanding (benchmark) terhadap imbal hasil riil diperlukan untuk menggantikan tingkat suku bunga pasar sebagaimana digunakan dalam persamaan (1). Gagasan terhadap pembentukan pembanding terhadap imbal hasil riil pada kenyataannya juga didukung oleh sejumlah pakar syariat untuk menggantikan LIBOR atau tingkat suku bunga pembanding yang saat ini banyak digunakan diseluruh dunia dalam menghitung imbal hasil untuk instrumen keuangan syariat.

Namun demikian, suatu model valuasi sukuk yang secara ketat mengikuti hukum syariat adalah suatu model yang selalu menghasilkan harga pasar sukuk pada nilai nominal pokoknya sepanjang waktu. Dalam hal ini, antisipasi pembagian kupon di masa mendatang tidak akan diperhitungkan dalam menentukan nilai pasar dari sukuk, sehingga tidak ada efek penggandaan uang. Pada kenyataannya, valuasi seperti inilah yang terjadi dalam perdagangan sukuk di Arab Saudi (Marek, 2007). Meskipun demikian, beberapa pihak mungkin akan berpendapat bahwa model valuasi yang ketat semacam ini adalah sulit untuk diterapkan karena tidak memperhitungkan risiko gagal bayar (default risk) dan biaya oportunitas (opportunity cost) atas sukuk itu sendiri. Risiko gagal bayar 
adalah suatu risiko dimana penerbit instrumen utang gagal membayar kembali pokoknya. Dalam pemahaman investor tradisional, seorang pembeli akan menawar pada harga diskon ketika dia memiliki persepsi bahwa penerbit sukuk memiliki probabilitas akan gagal bayar dan atau ketika imbal hasil pembanding lebih tinggi daripada imbal hasil sukuk. Sebaliknya, seorang penjual akan meminta pada harga premi ketika imbal hasil pembanding lebih rendah daripada imbal hasil sukuk. Semua hal tersebut sepenuhnya mengikuti proses persamaan (1). Akan tetapi, perdagangan sukuk yang melibatkan diskon dan premi semacam ini akan bertentangan dengan hukum syariat ketika sukuk diperdagangkan mengikuti aturan hawalah (pengalihan utang).

Pada masa kini, mungkin sebagian investor akan enggan memperdagangkan sukuk mereka karena persepsi bahwa mekanisme perdagangan sukuk saat ini tidak mengikuti ketentuan syariat, sebagai imbasnya mereka akan lebih memilih memegang sukuk mereka hingga jatuh tempo daripada terlibat dalam aktivitas yang tidak mengikuti syariat. Di sisi lain, sebagian investor juga mungkin akan enggan untuk memperdagangkan sukuk mereka jika sukuk dihargai pada nilai nominalnya untuk mematuhi hukum syariat, mengingat hal ini tidak memperhitungkan risiko gagal bayar dan biaya oportunitas. Tantangan sekarang adalah memperkenalkan suatu mekanisme perdagangan sukuk yang baru yang mampu mematuhi kepada hukum syariat namun juga mampu mengakomodasi proses valuasi sebagaimana obligasi konvensional. Adanya mekanisme perdagangan semacam ini akan menarik investor tradisional karena mereka akan cukup mengenal dengan proses valuasinya dan akan menarik investor yang sangat memerhatikan aturan syariat karena mereka memperoleh kepastian bahwa perdagangan yang dilakukan memenuhi aturan syariat. Pada akhirnya, apabila hal ini terjadi akan mampu mendorong likuiditas dan volume sukuk, sehingga semakin mendongkrak sukuk sebagai suatu instrumen alternatif terhadap obligasi konvensional.

Menurut ketentuan syariat, sukuk dapat diperdagangkan pada pasar sekunder pada nilai pasar selama hal ini mengikuti aturan hawalah. Namun masalahnya saat ini adalah banyak sukuk yang diperdagangkan di pasar sekunder mengikuti konsep bai' al dayn dan bukannya hawalah. Sebagian besar investor tradisional mungkin tidak akan bersedia untuk menerima konsep hawalah, karena dalam konsep hawalah penjual sukuk masih akan terikat kewajiban kontinjensi dengan pembeli sukuk meskipun mereka telah menjual sukuk kepada pembeli. Oleh sebab itu, suatu mekanisme perdagangan yang baru diperlukan untuk mendorong investor tradisional secara sukarela memperdagangkan sukuk dibawah konsep hawalah.

Salah satu jalan untuk mendorong investor tradisional menerima konsep hawalah adalah dengan memperkenalkan pihak ketiga atau suatu agen yang berfungsi menerima kewajiban kontinjensi dari penjual sukuk ketika mereka menjual sukuknya kepada pembeli. Agen ini pada dasarnya bertindak sebagai pihak yang akan membantu pembeli sukuk ketika penerbit sukuk gagal memenuhi kewajiban mereka. Mekanismenya adalah sebagai berikut: ketika penjual menjual sukuk kepada pembeli pada harga pasar, harga diskon, atau premi terhadap nilai nominal, penjual mengalihkan kewajiban kontinjensi hawalah-nya kepada seorang agen, katakan agen hawalah, dengan suatu fee atau imbalan. Sejak pengalihan itu, jika penerbit sukuk gagal memenuhi kewajibannya, pembeli sukuk akan merujuk kepada agen hawalah untuk membantu penyelesaian masalah gagal bayar tersebut dan bukannya kepada penjual. Agen hawalah haruslah suatu pihak yang memahami dengan baik mengenai kondisi pihak penerbit sukuk sehingga fee atau imbalan yang akan dibebankan kepada penjual dapat efisien. Dalam hal ini, badan pemeringkat (rating agency) adalah kandidat yang baik untuk bertindak sebagai agen hawalah.

Mekanisme ini memberikan kenyamanan kepada para investor mengingat sukuk dapat diperdagangkan pada nilai pasar, pada harga diskon maupun premi terhadap nilai nominalnya. Mekanisme ini dapat pula mendorong para investor yang sangat memerhatikan ketentuan syariat untuk memperdagangkan sukuk mereka karena mekanisme perdagangan ini telah mematuhi ketentuan dalam hukum syariat. 


\section{SIMPULAN}

Mekanisme perdagangan sukuk di pasar sekunder berbeda-beda pada setiap negara. Namun demikian, sebagian besarnya diperdagangkan mengikuti konsep bai' al dayn, yang mana hal tersebut tidak mengikuti aturan syariat. Adopsi terhadap konsep ini kemungkinan besar untuk memenuhi kebutuhan investor tradisional agar mudah dalam melakukan valuasi terhadap produk keuangan mereka. Di sisi lain, adopsi konsep tersebut menyebabkan investor yang sangat memerhatikan ketentuan syariat akan membatasi permintaan mereka untuk memperdagangkan sukuk karena tidak mematuhi aturan syariat. Suatu mekanisme perdagangan sukuk yang baru ditawarkan dengan memperkenalkan suatu agen hawalah. Peran agen hawalah adalah untuk mengambil alih kewajiban kontinjensi dari penjual sukuk dibawah konsep hawalah. Melalui pengaturan ini, pembeli sukuk akan merujuk kepada agen hawalah, dan bukannya penjual sukuk, jika penerbit sukuk gagal memenuhi kewajibannya. Oleh karena itu, investor tradisional dapat memperdagangkan sukuk mereka pada nilai pasar, yaitu pada harga diskon ataupun premi terhadap nilai parinya, sebagaimana harapan mereka dan investor yang sangat mematuhi ketentuan syariat dapat memperdagangkan sukuk mereka tanpa kuatir terhadap mekanisme perdagangan yang melanggar hukum syariat. Pada akhirnya, semua hal ini dapat mendorong lebih banyak investor untuk memperdagangkan sukuk mereka di pasar sekunder dan menambah likuiditas dan volume sukuk.

\section{DAFTAR PUSTAKA}

Ali, S. S. (2008). Islamic Capital Markets. Distance Learning Course No. 8. Islamic Research and Training Institute (IRTI). Islamic Development Bank (IDB). Jeddah.

Ayub, M. (2007). Understanding Islamic Finance. West Sussex, England: John Wiley \& Sons.

Brigham, E. F., Gapenski, L. C., and Daves, P. R. (1999). Intermediate Financial Management $6^{\text {th }}$ Edition. Fort Worth, USA: Dryden Press.

Heykal, M. (2006). Analisis Faktor Yang Mempengaruhi Margin Pembiayaan Murabahah Pada Pembiayaan Pemilikan Rumah, Studi Kasus PT Bank Syariah Mandiri, Jakarta: UI.

Jobst, A., Kunzel, P., Mills, P., and Sy, A. (2008). Islamic bond issuance: what sovereign debt managers need to know. International Jounal of Islamic and Middle Eastern Finance and Management. Vol. 1 No. 4, pp. 330-344.

Karim, A. (2012). Regulatory Aspect of Islamic Capital Market. Paper present at International Conference On Islamic Capital Market

Marek, S. (2007). The dawn of sukuk trading, International Securities Finance.

Papazian, A. V. (2007). The global sukuk market: developments and prospects. DIFC Forum.

Perwataatmadja, Karnaen A. (2002). Upaya Memurnikan Pelayanan Bank Syariah, Khusus Pembiayaan Murabahah dan Mudharabah di Indonesia, Artikel, Jakarta

Usmani, M. T. (2002). An Introduction to Islamic Finance. The Hague, Netherlands. Pp: Kluwer Law International,. 